\title{
Audit Fees and Financial Performance of Deposit Taking Saccos in North RIFT, Kenya
}

\author{
${ }^{1}$ Dorris Serem, ${ }^{2}$ Dr. Rashid Fwamba, ${ }^{3}$ Dr. Alala Benedict \\ 1,2Economics, Finance and Accounting department Kibabii University, Bungoma, Kenya \\ ${ }^{3}$ Economics, Finance and Accounting department Masinde Muliro University, Webuye, Kenya
}

\begin{abstract}
The collapse of Deposit-Taking SACCOS and financial institutions in Kenya has caught the attention of the public and supervisory agencies to query the quality of audit. SACCO Societies Regulatory Authority on its inspection report indicated that SACCOs have been implicated in maladministration, scams and fraudulent dealings that led to their eventual collapse. SASRA also revoked licenses and rejected audited financial statements of some Deposit Taking SACCOs between 2013 to 2017. These financial scandals have been traced to poor audit quality. The study aimed to test the impact of audit quality on financial performance of Deposit-Taking SACCOs in North Rift Region, Kenya. The study sought to establish the influence of audit fees on financial performance; determine the influence of audit firm tenure on financial performance; establish the influence of auditor independence on financial performance and to determine the influence of audit firm experience on financial performance of Deposit-Taking SACCOs in North Rift Region, Kenya. This study was based on Agency theory, Role theory and the Concept of audit expectation gap, and Stakeholders' theory. This research adopted descriptive cross-sectional research design. The target population for the study was 266 staff of all the 16 registered Deposit-Taking SACCOs in North Rift Region, Kenya. The sample size was 48 respondents comprising of chief executive officers, finance officers and internal auditors of the Deposit-Taking SACCOs selected using purposive sampling method. Primary and secondary data was used. Questionnaires collected primary data while audited annual financial statements of SACCOs provided secondary data. Inferential and descriptive statistics was used in analyzing data through SPSS version 25. It emerged that audit fees, audit firm tenure and audit firm experience have a significant positive influence on financial performance of Deposit-Taking SACCOs in North Rift Region, Kenya. Auditor independence had an insignificant positive influence on financial performance of DepositTaking SACCOs in North Rift Region, Kenya. The study concluded that audit quality has a positive noteworthy impact on financial performance of Deposit-Taking SACCOs in Kenya. The study recommends that regulatory authorities should formulate strict rules on audit fee charges and oversee the implementation of the same. Also, SASRA should ensure DT-SACCOs implement auditor rotation in compliance with auditing regulations and standards. DT-SACCOs to consider auditor's professional competence and experience before initiating any audit engagement. Finally, DT-SACCOs and auditors should reinforce the professional code of ethics in regard to auditor independence in terms of familiarity between auditor and the client that may lead audit work into jeopardy.
\end{abstract}

Keywords: Financial Market Performance, Audit Quality, Deposit, First and Secondary Data, Financial Statement

\section{Introduction}

\subsection{Background of the Study}

Audit quality in SACCOs has become a very interesting topic of discussion lately. It is defined as the market reviewed possibility that the statement of finance include material misstatement 
and that the auditor will both find out and reveal the misstatement (DeAngelo, 1981). Research suggests that the absence of excellence in audit is among the reasons behind the corporate and financial scandals that are happening across the globe (Soltani, 2014). Audit quality has a fundamental part in reinforcing trust in financial statements' accuracy and honesty which is necessary for improved output in financial performance of a SACCO (Farouk \& Hassan, 2014).

In Korea, a study conducted by Sonu, Choi, Lee, and Wonsuk, (2019) indicated that an auditor's skill has a constructive connection to audit quality. The relationship is more pertinent amongst non-Big 4 firms. This study demonstrated that many years of experience in audit improves the auditors work because auditors gain adequate experience in the profession over a given period of time. This study established that the acquaintance and expertise of the auditor grows over an extended period with actual client involvement. Another study by Kim, Lee, and Lee, (2015) suggests that better quality audit is achieved through compulsory auditor rotation. It is asserted that auditors who have been rotated recently are more inclined to give out a going concern opinion to a financially troubled company on initial audit compared with under Voluntary Audit Firm Transition.

In Ghana, Mawutor, Borketey and Obeng (2019) researched on elements affecting audit quality in registered firms. The study reveal that audit fee logarithm, audit committee and auditors' size were key to influence company leverage in Ghana. The study therefore concluded that the audit firms size is absolutely linked to audit efficiency. The total of audit fee charged touches audit quality in that an upsurge in audit fee upsurges the expenditures of the business which therefore reduces the profit of the company. The study further concludes that when the audit firm earns a significant revenue from the client,it makes the auditor to be economically dependent on the client.

In Kenya, financial scandals have also been experienced in the SACCO Sub-Sector. SASRA revoked a total of 7 operating licenses of DT-SACCOs between the periods 2014 to 2017 and rejected audited annual financial statements of Miliki Sacco, Uchongaji Sacco, Ainabkoi Sacco and Moi University Sacco for non-compliance of IFRS and inadequate disclosure of material issues in their audited annual financial statements (The SACCO Supervision Annual Report, 2017). Ekeza SACCO, Uchumi Supermarket, Kenya Airways, some Tuskys Supermarket outlets, Dubai Bank and Mumias Sugar Company are also among firms that experienced audit failures (Mwita, 2016). One similar trend in most of these company failures is that majority of them got excellent audit reports before collapsing (Dabor \& Dabor, 2015). In the year 2015 ICPAK issued stern regulation on auditors as a reaction to the rate of corporate failures. ICPAK therefore issued a guideline on mandatory auditor rotation to be every three years (ICPAK, 2015). The Big audit firms were put under investigation by ICPAK on suspicion of professional misconduct that led to failure of the companies they audited. Deloitte \& Touche audit firm in dealing with financial accounts of Tuskys Supermarket, Cooper Motor Corporation Limited, Mumias Sugar, Chase Bank and Dubai Bank was spotlighted for professional wrongdoing (Musyoki, 2015).

\subsection{Statement of the Problem}

The alarming financial scandals and collapses of SACCOs in Kenya related to mismanagement, deception and unethical activities draws attention to audit quality matters from the public and regulatory bodies (Mwita, 2016; Nasubo, 2019). SASRA revoked the licenses of 7 DT-SACCOs between the periods 2014 to 2017 and rejected audited annual financial statements of Miliki Sacco, Uchongaji Sacco, Ainabkoi Sacco and Moi University Sacco for non compliance of IFRS and inadequate disclosure of material issues in their audited annual financial statements (The SACCO Supervision Annual Report, 2017). Moi University Sacco lost Ksh.4 billion members savings in 2017 through mismanagement (Michira, 2019) while Bandari Sacco lost Ksh. 5 Million in 2015 through accounting fraud (Nasubo, 2019). 
SASRA has made various developments in regulations of auditors in the DT-SACCO in terms of audit firm term, auditor unconventionality, audit charges and audit firm experience. Despite the apparent far-reaching developments in the DT-SACCO Subsector in Kenya, research on how financial performance is influenced by audit quality is still a faint subject. There have been mixed results from empirical studies covering effects of quality auditing on fiscal performance, and no notable study has provided conclusive evidence to clarify the position. For example, research by El Guindy \& Basuony (2018) indicate that elongated auditor term improves audit quality of the firm, while a study by Adeniyi \& Mieseigha (2013) suggest that extended audit firm tenure affects audit quality negatively by derailing chances of quality audit and escalating threats. These studies show a split perspective on the performance contribution of audit quality. The aim of this study is, because of this mixed opinion, to analyze the effect auditing fees, audit firm tenure, auditor independence and audit firm experience on DT-SACCOs financial performance in Kenya. Studies on audit quality in nations like Spain and Indonesia have been done. Scanty evidence is available on audit quality and financial performance from a Kenyan context. During the analysis period, many countries have different characteristics of their variables, and hence the need in developing economies to examine these factors. Therefore, the researcher was encouraged to analyze and highlight the audit quality and performance relationship of DTSACCOs in Kenya, North Rift Region.

\subsection{General Objective}

To establish the influence of audit fees on the financial performance of Deposit Taking SACCOs in North Rift Region, Kenya

\subsection{Research Hypothesis}

Ho1: $\neg$ Audit fee has no significant influence on the financial performance of Deposit-Taking SACCOs in North Rift Region, Kenya.

\subsection{Conceptual Framework}

The conceptual structure uses the variable relationship in research analysis (Ravitch \& Riggan, 2012). Audit quality is the independent variable proxied by audit fees, audit firm tenure, auditor's independence and audit firm experience. Return on Assets(ROA) is used to calculate financial performance which is the dependent variable.
Independent variable
Dependent variable

\begin{tabular}{|c|c|c|}
\hline Audit fees & & \\
\hline - Client profitability & Hol & $\begin{array}{l}\text { Financial } \\
\text { Performance }\end{array}$ \\
\hline $\begin{array}{l}\text {-Client firm size } \\
\text {-Audit firm size }\end{array}$ & & Return on Assets \\
\hline
\end{tabular}

Figure 1: Conceptual framework

(Researcher, 2020)

\section{Literature Review}

\subsection{Agency Theory}

It was postulated in 1976 by Jensen and Meckling. This theory elucidates the connection between agents and principals. In 2010, Lan and Heracleous further developed this theory by 
providing a suggestion on the philosophy of agencies to three main aspects: redefine who is the principal, re-determine board rank, and redefine board role (Lan \& Heracleous, 2010).

In a SACCO, the principals are the shareholders, while the SACCO management is the agent. Shareholders delegate decision making authority to SACCO management. Differences of opinion and differences in priorities and interests are bound to arise between the shareholders and the management since shareholders delegate decisions involving finances to management.

Jensen and Meckling (1976) opine that more information is available to agents than the principals. This information asymmetry affects the shareholder's ability to know the extent to which management has met their interests in the SACCO. Shareholders are not in a position to determine whether the actions of the management are by their interests since shareholders cannot access all the available information during decision making. Therefore, the shareholders have to incur a monitoring cost by utilising auditors to reduce this information asymmetry. The theory of the Agency acknowledges audit as one of the vital oversight mechanisms for conflict of interest resolution and organisation cost reduction (Adeyami \& Fagbemi, 2010). Louise (2005) observes that audits are important in that they boost assurance and reinforces faith in financial information delivered to shareholders through management. According to Mutiso and Kamau (2013), accountability is good as it gives financial data transparency which is an essential concept for good corporate governance. Financial reports are the eye through which stakeholders can see the financial performance of the management to determine whether they are making sound investment decisions for shareholders wealth maximisation. These financial statements presented by management should be credible (Grace \& Ambrose, 2013). To issue quality reports, auditors should objectively assess clients' performance and resist any demands from management (DeFond, Lim, \& Zang, 2012; Carey \& Simnett, 2006). Audit report, therefore, gives assurance that the statements of finance show a factual and just situation of the SACCOs financial status.

\subsection{Empirical Literature Review}

\subsubsection{Audit Fees and Financial Performance}

The auditing fee shall be calibrated as the fee for time invested, the requisite facility and the number of audit workers (El-Gamal, 2012).

Moutinho, Cerquer and Brandão (2012) explored the association between audit fees and firm results in the US publicly listed, non-financial businesses, from 2000 to 2008 . The study used secondary data collected from a sample of 2656 from a population of 2881 firms. The study found out that increase in operating performance is related to a decrease in audit fees and vice versa. The study argues that auditors have a potential role in determining the economic situation of client businesses, which means that the necessary audit fees may be a fair measure of a how well a particular company is doing. The study found that more risky clients need more rigorous audit procedures leading to high audit charges.

Karsemeijer (2012) conducted a study on the relationship of audit charges and audit quality among listed firms in the USA through descriptive research architecture on a sample of 2568 companies in the USA. Data analysis was performed using the model of regression. The study shows that audit fees and the absolute value of discretionary accruals are positively and significantly linked. The study found out that, when audit fees are higher, the more critical the client has to be for the company, thereby losing independence and consistency.

Martinez and Moraes (2014) conducted a study in Brazil concerning the link between independent auditors' fees and firm performance from 2009 to 2011. The study adopted descriptive research design. There were 300 publicly traded companies in the sample population. The study used Tobin Q square and total assets to measure financial performance. The results show that higher audit fees serve as a market signal. Findings show that the audit 
fees and their company value relate positively. The results of the studies further showed that high audit fees are paid for by companies with high audit quality that enhances their firm value.

\section{Research Methodology}

\subsection{Research Design}

The study adopted descriptive cross-sectional research concept. This design is suitable when the problem is specifically identified and the researcher has certain issues that respondents are required to describe (Kothari, 2004) about a specified period (Cooper \& Schindler, 2011). This design was suitable for this study in describing audit characteristics of auditors and audit firms within DT-SACCOs for the given five year study period, and after that, a conclusion about the entire population was drawn from the outcome. Therefore, this design brings out an understanding of an existing link between audit quality and financial performance of DTSACCOs.

\subsection{Study Population}

Mugenda and Mugenda (2013) describe the population as a whole group of individuals, case or items having universal recognisable attributes. The study population was 266 staff of the 16 DT-SACCOs in North Rift Region that were dully registered and licensed by SASRA as at 31 December 2017 (SASRA Annual Supervision Report, 2017).

Table 1: Population

\begin{tabular}{|l|l|l|}
\hline No. & Name of the Sacco & Number of employees \\
\hline 1. & Trans-National Times Sacco Society Ltd & 33 \\
\hline 2. & Ainabkoi Sacco Society Limited & 9 \\
\hline 3. & Baraton University Sacco Society Limited & 10 \\
\hline 4. & The Noble Sacco Society Limited & 33 \\
\hline 5. & Kolenge Sacco Society Limited & 10 \\
\hline 6. & Nandi Farmers Sacco Society Limited & 12 \\
\hline 7. & Nandi Hekima Sacco Society Limited & 5 \\
\hline 8. & Trans- Elite Sacco Society Limited & 13 \\
\hline 9. & Prime -Time Sacco & 24 \\
\hline 10. & Smart Life Sacco & 25 \\
\hline 11. & Boresha Sacco & 25 \\
\hline 12. & Skyline Sacco & 12 \\
\hline 13. & Eco-pillar Sacco Society Limited & 9 \\
\hline 14. & Supa Sacco Society Limited & 22 \\
\hline 15. & Trans-Counties Sacco Society Limited & 11 \\
\hline 16 & Dumisha Sacco Society Limited & 13 \\
\hline & Total & $\mathbf{2 6 6}$ \\
\hline
\end{tabular}

Source: The SACCO Supervision Annual Report (2017)

\subsection{Sampling Design and Sample Size}

This study engaged purposive sampling in choosing respondents. The purposive sampling method is applicable in research in a case where the sampling informants have a specific type of knowledge or experience (Etikan, Musa, \& Alkassim, 2016). These prospective participants are capable of representing the SACCO and answering questions effectively. Thus, the study respondents for this study were chief executive officers, finance officers and internal auditors from each of the 16 DT-SACCOs since they have the adequate knowledge on financial statements of the DT-SACCO, therefore, they are in a position to represent the SACCO effectively. Therefore, these employees made a sample size of 48 respondents. 


\subsection{Data Collection}

Secondary and primary sources informed this research. Closed-ended questionnaire helped to obtain primary data. The five point Likert scale was used to rank the enquiries for ease of analysis. The selected respondents were issued with the questionnaires and were allowed to respond to the questionnaires which were collected at a later agreed time. Respondents got an explanation on the intention and rationale of the study and the importance of their input in the study before they were given the questionnaire to fill. Follow up was done on the respondents to achieve a reasonable number of dully filled up questionnaires.

\subsection{Data Analysis and Presentation}

SPSS version 25 was used to analyse descriptive and inferential data. Data collected was converted into frequency distribution tables and percentages using descriptive analysis (Kothari,2011). Data on inferential statistics was analysed using correlation and multiple regression analysis.

The regression model was in the form;

$Y=\beta 0+\beta 1 X 1+\beta 2 X 2+\beta 3 X 3+\beta 4 X 4+\varepsilon$

Where: Beta $(\beta)$ is the constant

$(\beta 0, \beta 1, \beta 2, \beta 3)$ are the regression coefficients

$Y=$ Financial performance

$\mathrm{X} 1$ = Audit fees

$\mathrm{X} 2$ = Audit firm tenure

$\mathrm{X} 3$ = Auditors' Independence

$\mathrm{X} 4=$ Audit experience

$\varepsilon=$ error term

\section{Data Analysis and Interpretation}

\subsection{Construct Validity}

This is the degree to which an instrument of data collection measures the actual hypothesis of the study (Bruce, 2008). This study adopted use of Kaiser-Meyer-Olkin (KMO) to measure sampling adequacy in order to ascertain that the number of items used to measure a particular construct (variable) were adequate. Bartlett's Test of Sphericity was used to measure if the items were coming from a population with equal variance.

Table 2: Sampling Adequacy and Sphericity Test Results

\begin{tabular}{|c|c|c|c|c|c|}
\hline \multirow{2}{*}{\multicolumn{2}{|c|}{ Variable }} & \multirow{3}{*}{$\begin{array}{l}\text { Kaiser-Meyer-Olkin } \\
\text { (KMO) Measure of } \\
\text { Sampling Adequacy }\end{array}$} & \multicolumn{3}{|c|}{ Bartlett's Test of Sphericity } \\
\hline & & & \multirow{2}{*}{$\begin{array}{l}\begin{array}{l}\text { Approx. } \\
\text { Chi- } \\
\text { Square }\end{array} \\
29.097\end{array}$} & \multirow{2}{*}{$\begin{array}{l}\begin{array}{l}\text { Degrees } \\
\text { of } \\
\text { freedom }\end{array} \\
10\end{array}$} & \multirow{2}{*}{$\begin{array}{l}\begin{array}{l}\text { p- } \\
\text { value }\end{array} \\
0.000\end{array}$} \\
\hline i. & Audit Fee & & & & \\
\hline ii. & Audit Firm Tenure & 0.587 & 75.748 & 21 & 0.000 \\
\hline iii. & Auditors Independence & 0.559 & 33.595 & 10 & 0.000 \\
\hline iv. & Audit Firm Experience & 0.576 & 29.972 & 10 & 0.001 \\
\hline v. & Return on Assets & 0.662 & 121.849 & 10 & 0.000 \\
\hline
\end{tabular}

Source: Pilot study results

The findings from Table 4.1 show that KMO results for sampling adequacy for all the six variables were above the minimum threshold value of 0.5 as established by (Engellant, 2016). KMO results for Audit fee was 0.729, Audit firm tenure was 0.587, Auditors independence was 0.559, Audit firm experience was 0.576 and Return on Asset was 0.662 . These results indicated an 
acceptable degree of sampling adequacy for all the factors. Significant results of Bartlett's Test of Sphericity indicated that the sampled items for each variable were from population with equal variance ( $p$-values $<.005)$ thus indicating an acceptable degree of sampling adequacy ; $(x 2$ $(10)=29.097, p=0.000<0.05)$ for Auditor Fee, $(x 2(21)=75.748, p=0.000<0.05)$ for Audit Firm Tenure, $(x 2(10)=33.595, p=0.000<0.05)$ for Auditors Independence, $(x 2(10)=29.972$, $p=0.001<0.05)$ for Audit Firm Experience and $(x 2(10)=121.849, p=0.000<0.05)$ for Return on Assets. According to Creswell and Creswell (2017), this data set passes the test; therefore the data set is fit for further analysis.

Table 3: Factor Analysis for Audit Fee

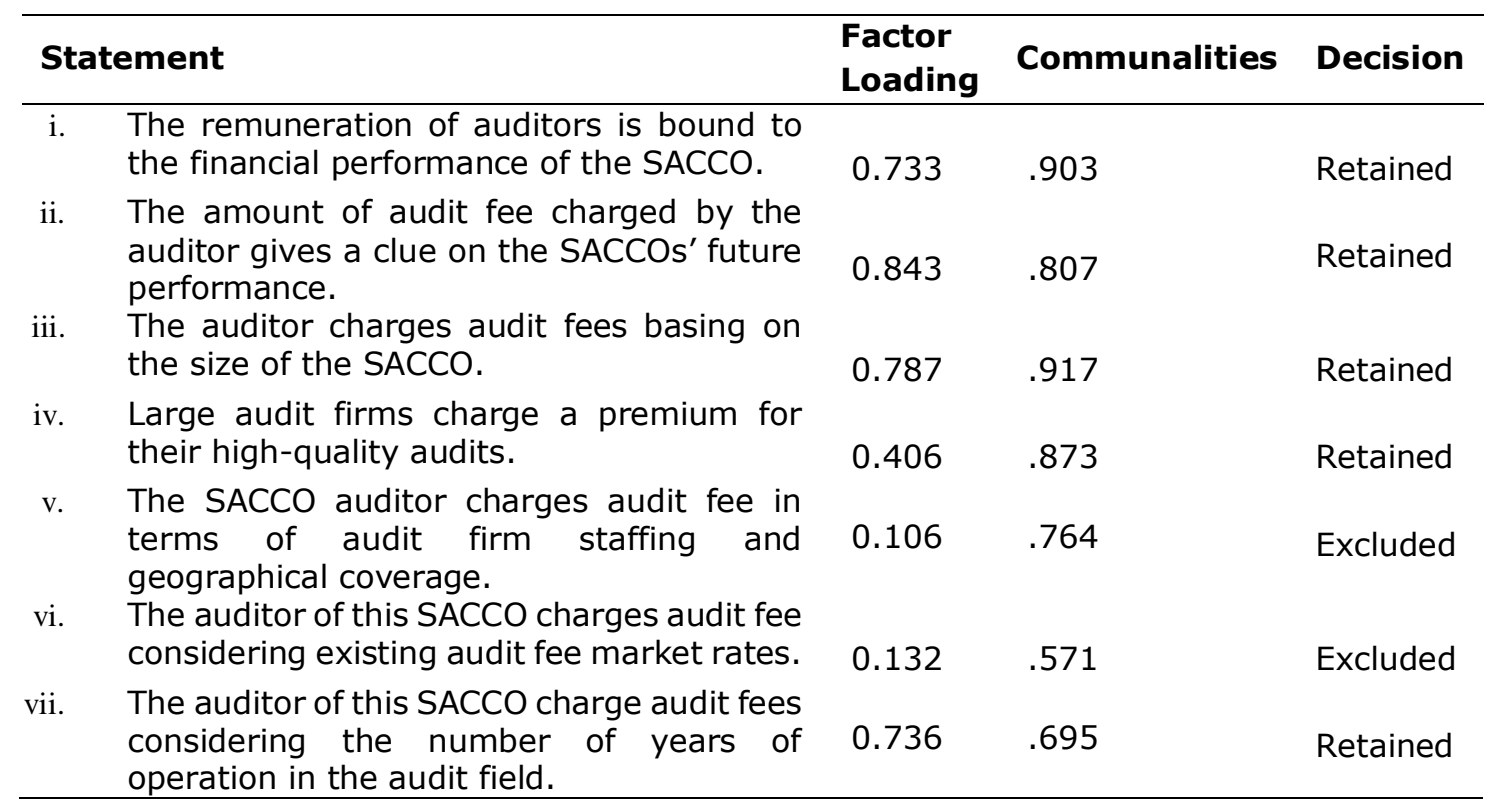

Source: Pilot study results

Table 4.2 shows that communalities for Audit Fee were all above 0.3 thresholds (Costello \& Osborne, 2005); thus, indicating that items under Audit Fee shared common variance on 5point Likert scale used. Only five items (i, ii, iii, iv and vii) under Audit Fee had factor loadings above the minimum threshold of 0.4 (Creswell, 2014) thus were retained as they were declared valid while two items ( $v$ and $\mathrm{vi}$ ) had factor loadings below the minimum threshold of 0.4 , hence were excluded from the questionnaire.

\subsection{Descriptive Analysis for Financial Performance}

To attain the general objective of this study, the researcher collected and analysed secondary data on Return on Assets from annual statements of finance of the DT-SACCOs in North Rift Region, Kenya from 2013 to 2017.

Table 4: Financial Performance (ROA)

\begin{tabular}{lllll}
\hline Return on Assets & Mean & Std. Deviation & Minimum & Maximum \\
\hline Return on Assets(ROA) 2013 & $3.72 \%$ & 1.19342 & 1.00 & 6.00 \\
Return on Assets(ROA) 2014 & $3.60 \%$ & 1.35951 & 1.00 & 5.39 \\
Return on Assets (ROA) 2015 & $3.73 \%$ & 1.08381 & 1.00 & 5.50 \\
Return on Assets (ROA) 2016 & $4.16 \%$ & 1.43047 & 1.00 & 7.00 \\
Return on Assets (ROA) 2017 & $3.39 \%$ & 1.52563 & 1.00 & 5.73 \\
\hline
\end{tabular}


According to the respondents, majority of the SACCOs in North Rift Region, Kenya had a marginal financial performance in the year 2017 as indicated by a mean of 3.39\% (as shown in table 4.3). The SACCOs had the highest financial performance in the year 2016, as indicated by a mean of $4.16 \%$. By the end of the year 2017 , return on assets was the lowest with a mean of $3.39 \%$ indicating declining financial performance of DT-SACCOs. This is evidence that DTSACCOs financial performance is not stable. Financial stability is a vital tool that is used to gauge the ability of a SACCO to generate value on shareholders' equity (Akbas, 2012) and (Eng, 2013). To ensure the stability of a SACCO, the importance of a high-quality audit is incredibly fundamental as it enhances the reliance and assurance of the investors (Martinov-Bennie \& Kilgore, 2014).

\subsection{The Establishment of the Influence of Audit Fees on Financial Performance \\ 4.3.1 Descriptive Analysis}

The first study objective was to establish the influence of audit fees on the financial performance of DT-SACCOs in North Rift Region, Kenya.

Table 5: Descriptive Analysis for Audit Fee

\begin{tabular}{|c|c|c|c|c|c|c|c|}
\hline \multicolumn{2}{|l|}{ Statement } & \multicolumn{2}{|c|}{$\begin{array}{l}\text { Strongly } \\
\text { Disagree }\end{array}$} & \multicolumn{2}{|c|}{ Disagree Undecided } & Agree & $\begin{array}{l}\text { Stron } \\
\text { gly } \\
\text { Agree }\end{array}$ \\
\hline \multirow{2}{*}{\multicolumn{2}{|c|}{$\begin{array}{l}\text { The remuneration of auditors is bound to } \\
\text { the financial performance of the SACCO }\end{array}$}} & \multicolumn{2}{|c|}{10} & 11 & 5 & 11 & \\
\hline & & \multicolumn{2}{|c|}{$24 \%$} & $27 \%$ & $12 \%$ & $27 \%$ & $10 \%$ \\
\hline \multirow{2}{*}{\multicolumn{2}{|c|}{$\begin{array}{l}\text { The amount of audit fee charged by the } \\
\text { auditor gives a clue on the SACCOs' future } \\
\text { performance. }\end{array}$}} & \multicolumn{2}{|l|}{12} & & 9 & 2 & 2 \\
\hline & & \multicolumn{2}{|c|}{$29 \%$} & $40 \%$ & $21 \%$ & $5 \%$ & $5 \%$ \\
\hline \multirow{2}{*}{\multicolumn{2}{|c|}{$\begin{array}{l}\text { The auditor charges audit fees basing on } \\
\text { the size of the SACCO. }\end{array}$}} & \multicolumn{2}{|l|}{1} & 2 & 2 & 16 & 21 \\
\hline & & \multicolumn{2}{|l|}{$2 \%$} & & $5 \%$ & $38 \%$ & $50 \%$ \\
\hline \multirow{2}{*}{\multicolumn{2}{|c|}{$\begin{array}{l}\text { Large audit firms charge a premium for } \\
\text { their high-quality audits. }\end{array}$}} & \multicolumn{2}{|l|}{2} & 8 & 6 & 7 & 19 \\
\hline & & $5 \%$ & & $19 \%$ & $14 \%$ & $17 \%$ & $45 \%$ \\
\hline The auditor of this SACCO charge & audit & 8 & & 9 & 15 & 8 & 2 \\
\hline $\begin{array}{l}\text { fees considering the number of yea } \\
\text { operation in the audit field. }\end{array}$ & irs of & $19 \%$ & & $21 \%$ & $36 \%$ & $19 \%$ & $5 \%$ \\
\hline General Audit Mean(\%Mean) & $\begin{array}{l}\text { Std. } \\
\text { Dev. }\end{array}$ & & $\begin{array}{l}\text { Std. } \\
\text { of } \mathrm{m}\end{array}$ & $\begin{array}{l}\text { Error } \\
\text { ean }\end{array}$ & Minimum & Maximı & um \\
\hline $2.1976(44 \%)$ & 0.37 & 513 & 0.057 & & 1.60 & 3.00 & \\
\hline
\end{tabular}

From table $4.4,27 \%$ of the respondents agreed, and another $27 \%$ disagreed that the remuneration of auditors is bound to the financial performance of the SACCO. $40 \%$ of the respondents disagreed that the amount of audit fees charged gives a clue on the SACCO's future performance. This finding not in line with that by (Martinez \& Moraes, 2014; Moutinho et al., 2012) who concluded that required audit fees might be a reasonable baton of the trend a particular firm's performance is heading. On the other side, $50 \%$ of the participants strongly agreed that the auditor charges audit fees basing on the size of the SACCO. This finding is consistent with that of Kimeli (2013), who concluded that audit client size is one of the factors that influence the amount of fee charged. Also, $45 \%$ of the respondents agreed that large audit 
firms charge a premium for their high-quality audits. This finding echo that of Kimeli (2013), who concluded that big audit firms charge high audit fee due to their reputation, industry specialisation, substantial staffing and big regional scope. Lastly, $36 \%$ of the respondents were uncertain whether auditors charge audit fees basing on the number of years of operation in the audit field.

Generally, the audit fees charged to most of the SACCOs in North Rift Region, Kenya seems to be moderate which is indicated by $44 \%$ mean response ( mean $=2.1976$, std. dev. $=0.37513$ )

\subsubsection{Correlation Analysis}

The study sought to determine the strength and direction of the relationship between Audit Fee and financial performance (Return on Assets) of DT-SACCOs in North Rift Region, Kenya. The Pearson Correlation analysis was used to establish the strength and direction of this relationship.

Table 6: Correlation between Audit fee and Financial Performance

\begin{tabular}{lll}
\hline & & Return on Assets \\
\hline \multirow{3}{*}{ Audit Fee } & Pearson Correlation coefficient $(r)$ & $0.399^{* *}$ \\
& Sig. (2-tailed) & 0.009 \\
& $\mathrm{~N}$ & 42 \\
\hline
\end{tabular}

The findings of Pearson Correlation analysis $(r=0.399, p$-value $=0.009<0.05)$ in table 4.5 indicate that there was a moderate positive correlation between Audit Fee and financial performance of DT-SACCOs in North Rift Region, Kenya.

\subsubsection{Simple Linear Regression between Audit Fee and Financial Performance of DT- SACCOs in North Rift Region, Kenya}

The researcher tested the following hypothesis regarding to audit fees;

H01: $\neg$ Audit fee has no significant influence on the financial performance of Deposit-Taking SACCOs in North Rift Region, Kenya

Table 7: Linear Regression Analysis between Audit Fee and Financial performance (Return on Assets) of DT-SACCOs in North Rift Region, Kenya.

\begin{tabular}{|c|c|c|c|c|c|}
\hline \multicolumn{6}{|l|}{ Model Summary } \\
\hline \multirow[b]{2}{*}{ Model } & \multicolumn{5}{|c|}{ Adjusted } \\
\hline & \multicolumn{2}{|l|}{ R Square } & \multicolumn{3}{|c|}{ R Square Std. Error of the Estimate } \\
\hline $.399^{\mathrm{a}}$ & .159 & & 0.44888 & & \\
\hline \multicolumn{5}{|c|}{$\begin{array}{l}\text { a. Predictors: (Constant), Audit Fee } \\
\text { b. Dependent Variable: Return on Assets }\end{array}$} & \\
\hline \multicolumn{6}{|c|}{ ANOVA } \\
\hline Model & Sum of Squares & Df & Mean Square & $F$ & Sig. \\
\hline 1 Regression & 1.526 & 1 & 1.526 & 7.573 & $.009^{\mathrm{b}}$ \\
\hline Residual & 8.060 & 40 & 0.201 & & \\
\hline Total & 9.586 & 41 & & & \\
\hline
\end{tabular}


Dorris Serem, Dr. Rashid Fwamba, Dr. Alala Benedict

Audit Fees and Financial Performance of Deposit Taking Saccos in North RIFT, Kenya

\begin{tabular}{|c|c|c|c|c|c|}
\hline \multicolumn{6}{|c|}{$\begin{array}{l}\text { b. Predictors: (Constant), Return on Assets } \\
\text { Coefficients }\end{array}$} \\
\hline \multirow[b]{3}{*}{ Model } & \multirow{2}{*}{\multicolumn{2}{|c|}{$\begin{array}{l}\text { Unstandardised } \\
\text { Coefficients }\end{array}$}} & \multirow{2}{*}{\multicolumn{2}{|c|}{$\begin{array}{l}\text { Standardised } \\
\text { Coefficients }\end{array}$}} & \multirow[b]{3}{*}{ Sig. } \\
\hline & & & & & \\
\hline & $\beta$ & Std. Error & Beta & $\mathrm{T}$ & \\
\hline 1 (Constant) & 0.941 & 0.416 & & 2.260 & .029 \\
\hline Audit Fee & 0.514 & 0.187 & 0.399 & 2.752 & .009 \\
\hline
\end{tabular}

The ANOVA test results from table 4.6 were $\mathrm{F}(1,40)=7.573, \mathrm{p}=0.009<0.05$; an indication that the Simple Linear Regression model was a good fit for our dataset. The model (Audit Fee) was able to explain $13.8 \%$ of the variation in DT-SACCOs financial performance in North Rift Region Kenya, as indicated by the Adjusted $\mathrm{R}$ Square $=0.138$. The regression Coefficient results showed that $\square=0.941, t=2.260, p=0.029<0.05$; therefore, the study rejected the null hypothesis and concluded that audit fee has a statistically significant impact on DT-SACCOs financial performance in North Rift Region. This finding is in line with that by (Martinez \& Moraes, 2014; Karsemeijer, 2012), who concluded that audit fee has a significant positive influence on the financial results of a firm. Audit Fee had a positive standardised beta coefficient $=0.399$ as shown in the coefficients results of Table 4.6; this indicates that a unit improvement in the audit fee was likely to result to an improvement in DT-SACCOs financial performance in North Rift Region, Kenya by 0.399 times. The following model can be used to predict the financial performance of the DT-SACCOs in North Rift Region Kenya when given the level of audit fee.

Financial Performance $=0.941+0.514$ Audit Fee

The model means that (holding other aspects unbroken) a unit increase in Audit Fee will lead to 0.514 times increase in DT-SACCOs financial performance in North Rift Region, Kenya.

Hypothesis 1 (H01) stated that $\neg$ audit fee has no significant influence on the financial performance of DT-SACCOs in North Rift Region, Kenya. In table 4.6, the study revealed that Audit Fee had a statistically significant partial influence in predicting DT-SACCOs financial performance in North Rift Region, Kenya as indicated by the significant unstandardised beta coefficients ( $\square=0.396, t=2.477$, $\mathrm{p}$-value $=0.018<0.05$ ) which was considered to be significant at $5 \%$ level of significance. Thus, the study rejects the null hypothesis and concludes that audit fee has a significant partial influence in predicting DT-SACCOs financial performance in North Rift Region, Kenya. These findings echo those of (Moutinho et al., 2012; Karsemeijer, 2012 ) in that audit fees and financial performance are positively and significantly linked.

The model for this study will be in the form;

$\mathrm{FP}=-0.015+0.396 \mathrm{AF}+0.129 \mathrm{AFT}+0.157 \mathrm{AI}+0.177 \mathrm{AFE}$

Where;

FP= Financial Performance of DT-SACCOs in North Rift Region, Kenya.

$\mathrm{AF}=$ Audit Fee

AFT = Audit Firm Tenure

AI $=$ Auditor's Independence

AFE $=$ Audit Firm Experience

The study used a standardised beta coefficient to establish the variable that had the greatest influence on the fiscal results of DT-SACCOs. If the value of standardised beta coefficient is nearer to one, then it has a greater effect on the dependent variable. The audit firm's experience in the multiple regression patterns greatly affected financial results led by audit fee, audit firm 
tenure and finally auditory independence, each with $0.357,0.307,0.285$ and 0.208 standardised beta coefficients respectively. On the individual simple linear regression model, auditor independence greatly affected fiscal results, followed by audit firm experience, audit firm tenure and finally by audit fee with a standardised beta coefficient of $0.643,0.606,0.404$ and 0.399 respectively. Generally, there is a reduced rate of improvement in financial performance for every unit increase in the independent variable on the multiple regression analysis. Results indicate that auditors' independence least influences financial performance in the presence of the other three variables in the multiple regression model, followed by audit firm tenure, audit fees and finally by audit firm experience.

\subsection{Summary of the Findings}

Coefficient results of simple and multiple regression analysis indicate that audit fee, audit firm tenure and audit firm experience have a statistically significant effect on DT-SACCOs financial performance. On the other hand, coefficient results of simple regression analysis indicate that auditor independence has a statistically significant influence on financial performance; however, auditor independence on the multiple regression analysis has a statistically insignificant influence on financial performance.

Correlation analysis indicates that all the independent variables (audit fee, audit firm tenure, auditor independence and audit firm experience) have a constructive association with the financial performance of DT-SACCOs in North Rift Region, Kenya.

To sum up, the study findings show that audit quality has a positive and statistically significant impact on the financial performance of DT-SACCOs in North Rift Region, Kenya. These findings concur with those of (Farouk \& Hassan, 2014; Muchugia, 2018; Matoke \& Omwenga, 2016) who also found a significant influence of audit quality on financial performance. Notably, audit quality, has a fundamental part in reinforcing trust in financial statements' accuracy and honesty which is necessary for improved output in the financial performance of a SACCO (Farouk \& Hassan, 2014). Therefore, audit quality serves a vital purpose in the stability and survival of a firm.

\section{Summary, Conclusion and Recommendations}

\subsection{Summary of the Findings}

The influence of audit quality on the financial performance of DT-SACCOs in the Kenyan North Rift Region was the study's objective. Audit quality was measured using four proxies audit fee, audit firm tenure, auditor independence and audit firm experience. Return on Assets (ROA) was used to measure financial performance. Correlation and regression analysis was used to test hypothesis. The general effect of the four variables indicates that they have a positive influence on the financial performance of DT-SACCOs. At $5 \%$ level of significance, based on the ANOVA, the model was found to be significant (jointly on all the four variables) and hence satisfactory for predicting DT-SACCOs the financial performance.

\subsubsection{Audit Fee and Financial Performance of DT-SACCOs}

The study findings point out that the audit fee was statistically significant in influencing DTSACCOs financial performance. From the study findings, it is not clear whether the remuneration of auditors is bound to the financial performance of the DT-SACCO. The outcome indicates that audit fee charged does not give a clue on the financial performance of the SACCO. Further, the study revealed that audit fee charged is dependent on the size of the SACCO and that big audit firms charges a premium for their high-quality audits. However, it is not certain on whether auditors charge audit fees depending on the number of years of operation in the audit field.

\subsection{Conclusions}

\subsubsection{Audit Fee and Financial Performance of DT-SACCOs}


The findings from the study have shown that the audit fee has a constructive and significant effect on financial performance. This is contributed by the fact that auditor's fee is based on the size of the SACCO rather than on their profitability which therefore enhances the financial performance of the DT-SACCOs. The study also concludes that big audit firms charge a premium for their high-quality audit. Big audit firms carry out a thorough audit to protect their reputation and issue quality reports which boost the financial performance of a firm.

\subsection{Recommendations for Policy}

i. Regulatory authorities such as ICPAK should formulate strict rules on audit fee charges and oversee the implementation of the same. From the study findings, the size of the DT-SACCO should be considered as a factor in the formulation of policies on audit fees.

ii. To add on, SASRA should ensure DT-SACCOs implement auditor rotation in compliance with auditing regulations and standards. This improves auditor independence, therefore increasing public confidence on the integrity of statements of finance.

\subsection{Suggestions for further Research}

Audit quality has not been explored fully by researchers. Therefore, more studies should concentrate in this field in different sectors of the economy. Also, the findings of the present study unveil that auditor independence has insignificant influence on the financial performance of DT-SACCOs. Therefore, more research should focus on this important role of auditor independence either singly or jointly with other variables (that this study has not covered) on the degree to which it influences the financial performance of different economic sectors.

Lastly, this study was limited to a period of five years. More research should expand the span of the study period to get a deeper understanding of the variables under study.

\section{References}

- Adeniyi, S., \& Mieseigha, E. (2013). Audit Tenure: An Assessment of its Effects on Audit Quality in Nigeria. International Journal of Academic Research in Accounting, Finance and Management Sciences, 3 (3), 275-283. Crossref

- Arens, J., et. al. (2014). Auditing and Assurance Service: Integrated Approach (15th ed.). USA: Pearson Education Publishers.

- Beattie, V., \& Fearnley, S. (2010). Auditor Independence and Non-Audit Services. A Literature Review. Working Paper.

- Cameran, M., Di Vincenzo, D., \& Merlotti, E. (2005). The audit firm rotation: A Review of Literature. Milan: Bacconi University. Crossref

- Dabor, E., \& Dabor, A. (2015). Audit committee characteristics, board characteristics and financial reporting quality in Nigeria. International Journal of Economics, Commerce and Management, 3 (11), 1292-1304.

- Dawkins, B. (2015). The role and function of external auditors.

- Jensen, M., \& Meckling, H. (1976). Theory of the Firm: Managerial Behavior, Agency Costs and Ownership Structure. Journal of Financial Economics, 3 (4). Crossref

- Kothari, C. R. (2011). Research Methodology, Methods \& Techniques. New Delhi: New age International Publishers.

- Mugenda, A., \& Mugenda, O. (2013). Quantitative and qualitative Approaches. Kenya: Nairobi: ACTS Press.

- Sejjaaka, K. (2005). "Compliance with IAS disclosure requirements by financial institutions in Uganda". Journal of African Business, 6 (1), 93-117. Crossref

- Selvam, S. (2017). Empirical research: A study guide Nairobi. Kenya: Paulines Publication.

- Warrad, L. (2012). Financial Reporting and Analysis, SchwerNotes TM for the CFA Exam, Level 1 , Book 1. 
Dorris Serem, Dr. Rashid Fwamba, Dr. Alala Benedict

Audit Fees and Financial Performance of Deposit Taking Saccos in North RIFT, Kenya

- World Bank. (2005). "Report on the Observance of Standards and Codes (ROSC): The Republic of Uganda". The World Bank, Washington, DC.

- Zikmund, P. (2008). Reducing the Expectation Gap. The CPA Journal, 78 (6), 20-25. 